\title{
Development of self-efficacy scale for music-assisted English teaching
}

Onur Köksal, Selçuk University, onurkoksal@selcuk.edu.tr, ORCID: 0000-0003-0798-3620

\begin{abstract}
The purpose of the present research is developing a scale to be used in measuring the English teachers' self-efficacy for music-assisted English teaching. For the validity and reliability studies of the scale, 185 English teachers were included in the research in 2019. For these processes, exploratory and confirmatory factor analyses were conducted, and item discrimination indices were calculated. Following these analyses, Cronbach Alpha reliability coefficient was calculated. Consequently, the scale consisted of 25 items that explained the $49.709 \%$ of the variance. Exploratory factor analysis revealed that the scale had three dimensions. Confirmatory factor analysis conducted on AMOS-21 in order to confirm the structure defined with exploratory factor analysis confirmed the three-dimensional model. Finally, test item correlations ranged between 0.288 and 0.742 , and the Cronbach Alpha coefficient was calculated as 0.915 .
\end{abstract}

Keywords: Self Efficacy, Music, English teaching

\section{INTRODUCTION}

Even many definitions have been made for the concept of self-efficacy, the most acknowledged one was made by Bandura (1986), as individuals' believing in their efficacy on achieving a predefined objective, managing and organizing the process and realizing the action (Akkoyunlu, Orhan and Umay, 2005). Based on the assumption that every individual is unique, individual differences of individuals affect their self-efficacy. On this, Schunk (1985) stated that self-efficacy, which is one of the individual variables, affected individuals' efforts and motivation towards learning. In the process of learning a new skill, individuals need to have the ability to organize this process in order to develop their existing skills or abilities (Bandura, 1997). This way, individuals can realize new learning. Therefore, self-efficacy is considered as a knot establishing the relationship between acquisition and ability (Schunk, 1985).

\section{Image-1 Relationship between Acquisition and Ability}

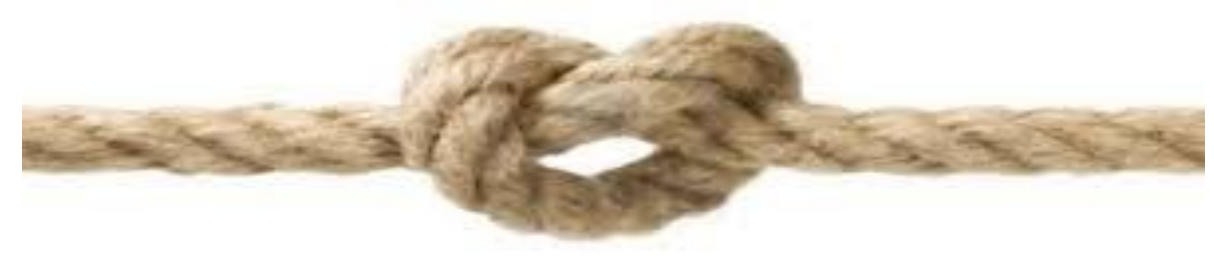

Based on the sense of achievement, self-efficacy is the most important factor that affects the individuals' motivation, effort and belief in success (Güvenç, 2010). Pajares (1996) states that the most important barrier preventing the perception of failure is self-efficacy, since self-efficacy is the most important source of motivation in believing in the success. If an individual has preexisting experience, had learnings by making and living, has well-founded knowledge and cope with the emotions like stress and anxiety during the process, this individual is considered to have achieved self-efficacy (Özmenteș, 2011). Self-efficacy is one of the most important factors in success (Kandemir and Özbay, 2012). Self-efficacy can also be defined as the actual skill in accomplishing a task (Ülper, Yaylı and Karakaya, 2013). The perception of self-efficacy is 
individuals' beliefs in themselves in terms of achieving objectives and performances defined cognitively (Farran, 2004). However, the lack of necessary conditions in achieving the skills, motivation and objectives can affect individuals' perception of self-efficacy (Kandemir and Özbay, 2012). As a result, the individuals tend to go for the actions they believe they can achieve and avoid the ones they do not believe they can achieve (Bandura, 1986). The source of this perception about whether an individual can or cannot achieve is the society they live in. The role of educational institutions that form the society is of utmost importance in this process, because the society should offer individuals with opportunities to use their existing knowledge and skills and have an educational policy to provide individuals with self-efficacy, as a system that prohibits, forces, pushes towards despair and judges in case of failure prevents the raising of individuals with self-efficacy.

From another perspective, self-efficacy is the awareness of the existing skills, rather than being skilled (Ylldırım and İlhan, 2010). Therefore, the education individuals receive should raise awareness among individuals on their skills and enable them using their existing skills. In this case, schools should provide individuals with academic self-efficacy perception. Srios (2004) defines the concept of academic self-efficacy as a process of perception that guide individuals' efforts to learn and achieve in actualizing the attainments. Zimmerman (1995) defines the concept of academic self-efficacy as individuals' beliefs in their skills related to learning.

Educational scientists have focused on ways of better learning and teaching processes in every study they have conducted (Yağışan, Köksal and Harun, 2014). Therefore, as education is considered as a living element, new theories, methods and techniques keep emerging constantly. At this point today, the necessity of using music by the teachers in education is undeniable. Recent studies have revealed that human nature is more open to learning through music and music contributes to individuals' learning (Köksal, Yağıșan and Çekiç, 2013). Campbell (2003) reports that music contributes to language skills, studying habits, memorization skills and audio-visual memories. Due to music's great contribution to learning and teaching process, language teaching through music is considered a sensible method, and many studies have been conducted in the related literature on the subject (Medina, 1990; Palmer and Kelly, 1992; Mora, 2000; Cengiz, 2004; Köksal, Yağışan and Çekiç, 2013). These experimental studies show that teaching foreign languages with music is an effective method. Köksal, Yağışan and Çekiç (2013) report that music enables students coding new vocabulary and remembering new structures and concepts easily in the foreign language learning process. This way, students present a more positive attitude towards foreign language and have no prejudices against learning (Köksal, Yağışan and Çekiç, 2013). Stansell (2005) reports that teaching foreign language through music creates a more positive environment in the classroom and makes new information more interesting and meaningful.

The idea that teaching foreign languages through music is also effective in the communicative dimension of the language has become prevalent, since music and language are related and intertwined concepts. Therefore, many studies have revealed that teaching foreign languages through music have many benefits, such as;

- vocabulary items are kept in memory longer,

- vocabulary items are remembered more easily,

- word and sentence stress are applied more accurately,

- word and sentence order are applied more accurately,

- students are concentrated more easily and for longer, and

- words are pronounced more accurately (Volin, 1997; Stansell, 2005; Šišková, 2008; Köksal, Yağışan and Çekiç, 2013).

Based on the aforementioned statements, it can be claimed that music assisted activities conducted by teachers in the classroom are very important. For an effective foreign language through music, musical abilities of foreign language teachers are also important. Therefore, feeling competent in the field, perceiving themselves skilled in music, being aware of these skills and most importantly their beliefs in themselves for language teachers can provide a successful foreign language teaching. The review of the related literature presents scale developments 
studies for other branches, yet no studies could be found on the development of self-efficacy scale for music-assisted English teaching.

Accordingly, the purpose of the present research is developing a scale to measure English teachers' self-efficacy on music-assisted English teaching. As the international literature includes many studies on self-efficacy scales on music or English teaching but none on music-assisted English teaching, there is a need for developing such a scale to be used in international studies.

\section{RESEARCH METHOD}

\section{Research Model and Work Group}

The present research adopts general scanning model. General scanning model enables scanning a whole universe or a group, or a sample in order to have a general judgement about a universe consisting of many elements (Karasar, 2005). With this model, researchers can have a general opinion about a group. The present research was conducted with analyses of the data collected from 185 English teachers serving at state or private schools.

\section{The Process of Developing Self-Efficacy Scale}

In the process of developing self-efficacy scale for music-assisted English teaching, English teachers were asked to write an essay on their ideas and feelings about music-assisted English teaching. These essays were analyzed and the statements about teachers' self-efficacy were selected. Additionally, related literature was reviewed, and statement similar to the statements in the items in the self-efficacy scales were formed. The statements from teacher essays and the related literature were compared and an item pool was formed using these statements. During this process, educational scientists were asked for their opinions, and they were asked to define each item as unacceptable, acceptable or must be included and also write down any items they thought they should be included in the scale. In order to have an opinion on the comprehensibility of the items and to make sure they are accurate structurally Turkish teachers were asked for their opinions. The items of the scale were graded as Strongly Agree, Agree, Disagree and Strongly Disagree. In order to avoid affecting teachers, the positive and negative items in the scale are presented in a mixed order. At the end of this process, 6 items, that were considered as unacceptable by all three experts were removed from the item pool, and 4 more items were included. As a result, a 35-item draft scale was formed. Finally, an instruction text informing about the purpose of the scale was included at the beginning of the scale. The draft scale was implemented on 185 English teachers.

In order to study the validity of the developed scale further in addition to expert opinions, the correlations between answers given to each item in the scale and the total score from the scale were calculated for item analysis. Results of the analysis are presented in findings section. This analysis presented a 3-dimensional scale and the items became ready for factor analysis.

Exploratory factor analysis was conducted in order to define the structure of the draft scale. Daniel (1995) states that exploratory factor analysis is conducted to factor structure based on variables. In order to confirm the structure defined with exploratory factor analysis, confirmatory factor analysis was conducted on AMOS-21 packaged software. This way, the factor structure of the draft scale was defined, and the validity of the scale was tried to be defined using this other factor structure. Fit index values were interpreted according to the criteria defined by Schermelleh-Engel, Moosbrugger and Müller (2003) and Byrne (2013). Confirmatory factor analysis revealed standardized factor load values for each item, regression coefficients and $t$ statistics. Additionally, since one item in each factor was fixed to non-standardized estimate value 1 , t statistics was not calculated for 3 items. However, factor load values for factor ways were high. In order to improve the fit index values in confirmatory factor analysis, modification ways were defined between items 10 and 11, 10 and 12, and 23 and 24. In order to prove the applicability of the scale, internal consistency Cronbach Alpha value was taken into consideration as is done in many scale development studies, and the development of the self-efficacy for musicassisted English teaching scale was completed. 


\section{FINDINGS}

\section{Construct validity}

Tavşancl (2002) defined construct validity as the scale's capability of measurement of the whole construct to be measured. Construct validity studies are conducted to reach at a common result and obtain values with high reliability in academic studies. Construct validity enables the explaining of the results obtained from the scale and what these results are related to (Akyüz, 2018). Therefore, in order to define the construct validity of the scale developed in the present research, exploratory and confirmatory factor analyses were conducted. First, exploratory factor analysis was conducted in order to define the factor structure of the scale. However, to be able to conduct exploratory factor analysis, the number of samples on which the scale is implemented should be adequate (Kahn and Best, 2017; Translated by: Köksal, 0). Kaiser- Meyer-Olkin (KMO) value should be calculated in order to define the sample size. The closer the obtained results are to 1 , the better it is, and if it is below .50, it is considered as unacceptable (Tavşancll, 2002), because distribution in the universe is expected to be normal in factor analysis (Karakaş and Turanl, 2008). Distribution in the universe was analysed with Barlett test. According to the results, KMO coefficient of the scale was 0.50 and the Barlett test significance value was 0.00 . These results show that the data collected from the teachers were fit for factor analysis. Component Matrix and Rotated Component Matrix-Varimax analyses were conducted to define the factor structure of the scale. For an item to be included in a factor, it must meet two requirements. In these values, the factor loads on the items should be above 0.35 and the items' factor load values should be 0.10 higher than its load values in the other factor (Tavşancll, 2002). According to the factor analysis conducted on 35 items in the scale, KMO coefficient was 0.898 and Barlett significance coefficient was 0.00 .

Table 1. Exploratory factor analysis results for self-efficacy for music-assisted English teaching scale

\begin{tabular}{|c|c|c|c|c|}
\hline Item No & Factor and Questions & $\begin{array}{c}\text { Cronbach } \\
\text { Alpha } \\
\text { Coefficient }\end{array}$ & $\begin{array}{c}\text { Variance } \\
\text { Explaining } \\
\text { Percentage }\end{array}$ & $\begin{array}{c}\text { Eigen } \\
\text { values }\end{array}$ \\
\hline & $1^{\text {st }}$ factor & 0,914 & 35,603 & 8,901 \\
\hline \multicolumn{5}{|l|}{ VAR00024 } \\
\hline \multicolumn{5}{|l|}{ VAR00025 } \\
\hline \multicolumn{5}{|l|}{ VAR00023 } \\
\hline \multicolumn{5}{|l|}{ VAR00026 } \\
\hline \multicolumn{5}{|l|}{ VAR00027 } \\
\hline \multicolumn{5}{|l|}{ VAR00022 } \\
\hline \multicolumn{5}{|l|}{ VAR00028 } \\
\hline \multicolumn{5}{|l|}{ VAR00034 } \\
\hline \multicolumn{5}{|l|}{ VAR00033 } \\
\hline \multicolumn{5}{|l|}{ VAR00032 } \\
\hline \multicolumn{5}{|l|}{ VAR00029 } \\
\hline \multicolumn{5}{|l|}{ VAR00035 } \\
\hline \multicolumn{5}{|l|}{ VAR00004 } \\
\hline & $2^{\text {nd }}$ factor & 0,739 & 8,066 & 2,017 \\
\hline \multicolumn{5}{|l|}{ VAR00016 } \\
\hline VAR00010 & & & & \\
\hline
\end{tabular}


Table 1. Continued

\begin{tabular}{lllll}
\hline VAR00006 & & & \\
\hline VAR00009 & & & & \\
\hline VAR00015 & $3^{\text {rd }}$ factor & 0,732 & 6,040 & 1,510 \\
\hline VAR00014 & & & \\
\hline VAR00005 & & & \\
\hline VAR00007 & & & \\
\hline VAR00002 & & & \\
\hline VAR00003 & & & \\
\hline VAR00001 & & & \\
\hline VAR00018
\end{tabular}

KMO Value $=0,898$, Explained Variance Total $=49,709$, Cronbach Alpha Coefficient $=0,915$

As presented in Table 1, 35.603 of the explained total variance explains first factor, 8.066 explains second and 6.040 explains third factor. Table shows that the total variance of the scale is 49.709 and the scale is three dimensional. The first dimension was titled "Self-efficacy for Teaching with Music", second was titles "Self-efficacy for Using Music in Classes" and the third was titled "Self-efficacy for Using a Musical Instrument" (Table 2).

Table 2. Self-efficacy Factor Titles

\begin{tabular}{|c|c|c|c|c|}
\hline \multicolumn{2}{|c|}{$\begin{array}{l}\text { Factor 1: Teaching with } \\
\text { Music }\end{array}$} & \multirow{2}{*}{$\begin{array}{c}\text { 1st Factor }^{\text {st }} \\
0,811\end{array}$} & \multirow[t]{2}{*}{$\begin{array}{c}\text { Variance } \\
\text { Explaining } \\
\text { Percentage } \\
35,603 \\
\end{array}$} & \multirow[t]{2}{*}{$\begin{array}{c}\text { Eigen } \\
\text { values } \\
\mathbf{8 , 9 0 1}\end{array}$} \\
\hline VAR00024 & $\begin{array}{l}\text { I think students enjoy classes more when } \\
\text { English is taught with music. }\end{array}$ & & & \\
\hline VAR00025 & $\begin{array}{l}\text { I think students can concentrate longer in } \\
\text { English classes done with music. }\end{array}$ & 0,805 & & \\
\hline VAR00023 & $\begin{array}{l}\text { I think English vocabulary learnt through } \\
\text { songs are more permanent. }\end{array}$ & 0,779 & & \\
\hline VAR00026 & $\begin{array}{l}\text { I think using music fitting the emotional } \\
\text { mood of the stories taught in English } \\
\text { classes can contribute to teaching more } \\
\text { effectively. }\end{array}$ & 0,751 & & \\
\hline VAR00027 & $\begin{array}{l}\text { I think I can express myself better when I } \\
\text { use music in English classes. }\end{array}$ & 0,709 & & \\
\hline VAR00022 & $\begin{array}{l}\text { I think English can be pronounced more } \\
\text { fluently and easily using music. }\end{array}$ & 0,664 & & \\
\hline VAR00028 & $\begin{array}{l}\text { I can teach subjects more creatively using } \\
\text { music. }\end{array}$ & 0,636 & & \\
\hline VAR00034 & $\begin{array}{l}\text { I can teach subjects more easily using } \\
\text { music in English classes. }\end{array}$ & 0,635 & & \\
\hline VAR00033 & $\begin{array}{l}\text { I think using music in English classes } \\
\text { contributes to course attainments } \\
\text { positively. }\end{array}$ & 0,629 & & \\
\hline VAR00032 & $\begin{array}{l}\text { I can teach more effectively when I use } \\
\text { music in English classes. }\end{array}$ & 0,607 & & \\
\hline
\end{tabular}


Table 2. Continued

\begin{tabular}{|c|c|c|c|c|}
\hline VAR00029 & $\begin{array}{l}\text { I think using music in English classes } \\
\text { contributes to my professional } \\
\text { development. }\end{array}$ & 0,589 & & \\
\hline VAR00035 & $\begin{array}{l}\text { I don't think using music in English } \\
\text { classes in necessary. }\end{array}$ & 0,513 & & \\
\hline VAR00004 & $\begin{array}{l}\text { I believe I can develop students' creativity } \\
\text { with music assistance in English classes. }\end{array}$ & 0,502 & & \\
\hline $\begin{array}{l}\text { Factor 2: } \\
\text { Using } \\
\text { Music }\end{array}$ & Factor and Items & $2^{\text {nd }}$ Factor & $\begin{array}{l}\text { Variance } \\
\text { Explaining } \\
\text { Percentage } \\
8,066\end{array}$ & $\begin{array}{l}\text { Eigen } \\
\text { Values } \\
2,017\end{array}$ \\
\hline VAR00016 & $\begin{array}{l}\text { If students have difficulty in learning new } \\
\text { vocabulary in English, I can make them } \\
\text { learn better using music. }\end{array}$ & 0,696 & & \\
\hline VAR00010 & $\begin{array}{l}\text { I believe I am able to teach students an } \\
\text { English song correctly. }\end{array}$ & 0,640 & & \\
\hline VAR00006 & $\begin{array}{l}\text { I am able to teach students correct } \\
\text { pronunciation using music. }\end{array}$ & 0,635 & & \\
\hline VAR00009 & $\begin{array}{l}\text { I am able to teach students word stress in } \\
\text { English classes using various rhythmic } \\
\text { activities. }\end{array}$ & 0,604 & & \\
\hline VAR00015 & $\begin{array}{l}\text { I can increase participation in English } \\
\text { classes using music. }\end{array}$ & 0,532 & & \\
\hline VAR00014 & $\begin{array}{l}\text { I am able to find different music-assisted } \\
\text { methods in English teaching. }\end{array}$ & 0,522 & & \\
\hline $\begin{array}{l}\text { Factor 3: } \\
\text { Using } \\
\text { Instrument }\end{array}$ & Factors and Items & $3^{\text {rd }}$ factor & $\begin{array}{c}\text { Variance } \\
\text { Explaining } \\
\text { Percentage } \\
\mathbf{6 , 0 4 0} \\
\end{array}$ & $\begin{array}{c}\text { Eigen } \\
\text { Values } \\
\mathbf{1 , 5 1 0}\end{array}$ \\
\hline VAR00005 & $\begin{array}{l}\text { I don't think I am able to use and } \\
\text { implement different teaching methods } \\
\text { using music in English classes. }\end{array}$ & 0,668 & & \\
\hline VAR00007 & $\begin{array}{l}\text { I don't think I am able to use music in } \\
\text { English events organized at school. }\end{array}$ & 0,661 & & \\
\hline VAR00002 & $\begin{array}{l}\text { I believe I can motivate students } \\
\text { effectively in English classes using music- } \\
\text { assistance. }\end{array}$ & 0,570 & & \\
\hline VAR00003 & I am able to use a music in English classes. & 0,560 & & \\
\hline VAR00001 & $\begin{array}{l}\text { I am able to use a musical instrument in } \\
\text { English classes. }\end{array}$ & 0,544 & & \\
\hline VAR00018 & $\begin{array}{l}\text { I have adequate repertoire of English } \\
\text { songs to use in English classes. }\end{array}$ & 0,526 & & \\
\hline
\end{tabular}

Eigen values for factor (scree plot) graph also shows that the scale has three dimensions. Scree Plot graph is presented below. 


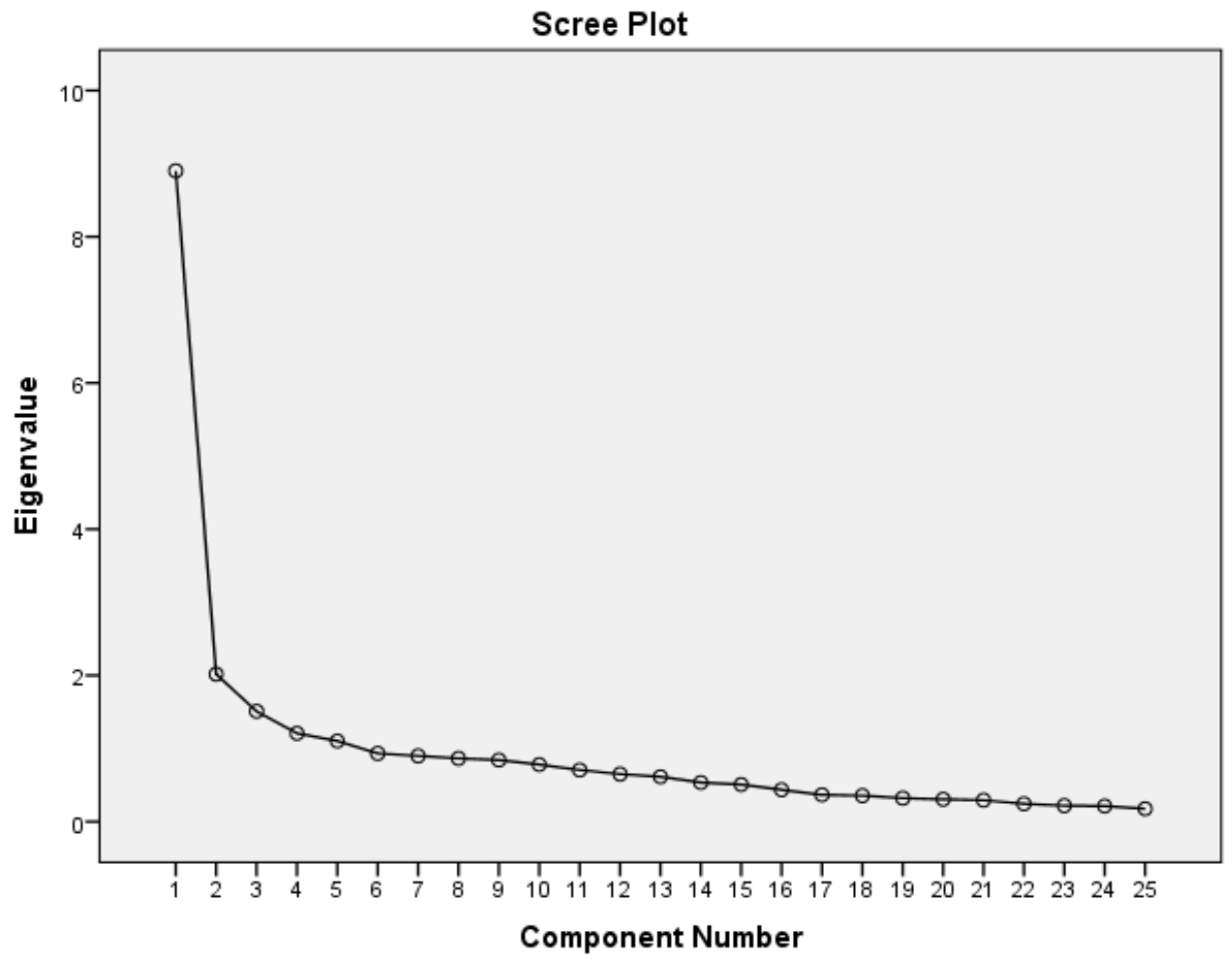

GRAPH 1. Scree Plot Graph

As presented in scree plot graph, eigen value of every item in the scale is above 1 . The most drastic fall is in the first factor. Therefore, that the first factor explains $35 \%$ of the total variance shows that the scale has 3 dimensions (Büyüköztürk, 2011). Results of the Rotated Component Matrix-Varimax analysis is presented below.

Table 3. Factor Load Values According to Rotated Component Matrix-Varimax Analysis

\begin{tabular}{|c|c|c|c|c|}
\hline Item No & Factor and Items & $1^{\text {st }}$ Factor & 2nd Factor & $3^{\text {rd }}$ Factor \\
\hline VAR00024 & & 0,811 & & \\
\hline VAR00025 & & 0,805 & & \\
\hline VAR00023 & & 0,779 & & \\
\hline VAR00026 & & 0,751 & & \\
\hline VAR00027 & & 0,709 & & \\
\hline VAR00022 & & 0,664 & & \\
\hline VAR00028 & & 0,636 & & \\
\hline VAR00034 & & 0,635 & & \\
\hline VAR00033 & & 0,629 & & \\
\hline VAR00032 & & 0,607 & & \\
\hline VAR00029 & & 0,589 & & \\
\hline VAR00035 & & 0,513 & & \\
\hline VAR00004 & & 0,502 & & \\
\hline VAR00016 & & & 0,696 & \\
\hline VAR00010 & & & 0,640 & \\
\hline VAR00006 & & & 0,635 & \\
\hline VAR00009 & & & 0,604 & \\
\hline VAR00015 & & & 0,532 & \\
\hline VAR00014 & & & 0,522 & \\
\hline
\end{tabular}


Table 3. Continued

\begin{tabular}{lc}
\hline VAR00005 & 0,668 \\
\hline VAR00007 & 0,661 \\
\hline VAR00002 & 0,570 \\
\hline VAR00003 & 0,560 \\
\hline VAR00001 & 0,544 \\
\hline VAR00018 & 0,526 \\
\hline
\end{tabular}

Load values of the items range between 0.502 and 0.811 . After the rotation, the scale is still three-dimensional. As also presented in Eigenvalue-factor graph, the most drastic fall is in the first factor. Total variance value of the first factor is $35.603 \%$.

As a result of the all analyses, 25 items were left in the scale. The table below presents the common factor total correlations of the items included in the scale.

Table 4. Common Factor Total Correlations of the Items

\begin{tabular}{ll}
\hline Items & Corrected Item-Total Correlation \\
\hline VAR00016 & 0,570 \\
\hline VAR00010 & 0,462 \\
\hline VAR00009 & 0,356 \\
\hline VAR00006 & 0,288 \\
\hline VAR00014 & 0,536 \\
\hline VAR00015 & 0,524 \\
\hline VAR00005 & 0,324 \\
\hline VAR00002 & 0,615 \\
\hline VAR00003 & 0,334 \\
\hline VAR00001 & 0,623 \\
\hline VAR00018 & 0,445 \\
\hline VAR00023 & 0,350 \\
\hline VAR00024 & 0,616 \\
\hline VAR00025 & 0,677 \\
\hline VAR00026 & 0,742 \\
\hline VAR00027 & 0,645 \\
\hline VAR00022 & 0,656 \\
\hline VAR00028 & 0,540 \\
\hline VAR00032 & 0,566 \\
\hline VAR00033 & 0,611 \\
\hline VAR00034 & 0,625 \\
\hline VAR00029 & 0,666 \\
\hline VAR00035 & 0,471 \\
\hline & 0,497 \\
\hline VAR0004 & 0,610 \\
\hline
\end{tabular}

As presented in Table 4, common factor variances of the items range between 0.288 and 0.742 and the factor load values of the items are grouped in three factors. After all procedures, a valid measurement item of 25 items and three dimensions was obtained.

Confirmatory factor analysis was conducted on 25 items in order to define the extent to which the items left in the scale after exploratory factor analysis can measure.

Confirmatory factor analysis was conducted in the steps. In the first step, fit indices and modification indices according to confirmatory factor analysis results were obtained. Based on the results, modification indices were analysed for the fitness of the factor structure of the items with the data. Based on the modification indices, inter-items modification ways were defined in order to improve item fit index values. 
Figure 1 presents standardized factor load values, regression coefficients, $t$ statistics for each item according to confirmatory factor analysis 1st Level 3-Factor DFA model for self-efficacy scale. Additionally, since one item in each factor was fixed to non-standardized estimate value 1 , t statistics was not calculated for 3 items. However, factor load values for factor ways were high. In order to improve the fit index values in confirmatory factor analysis, modification ways were defined between items 10 and 11,10 and 12, and 23 and 24 .

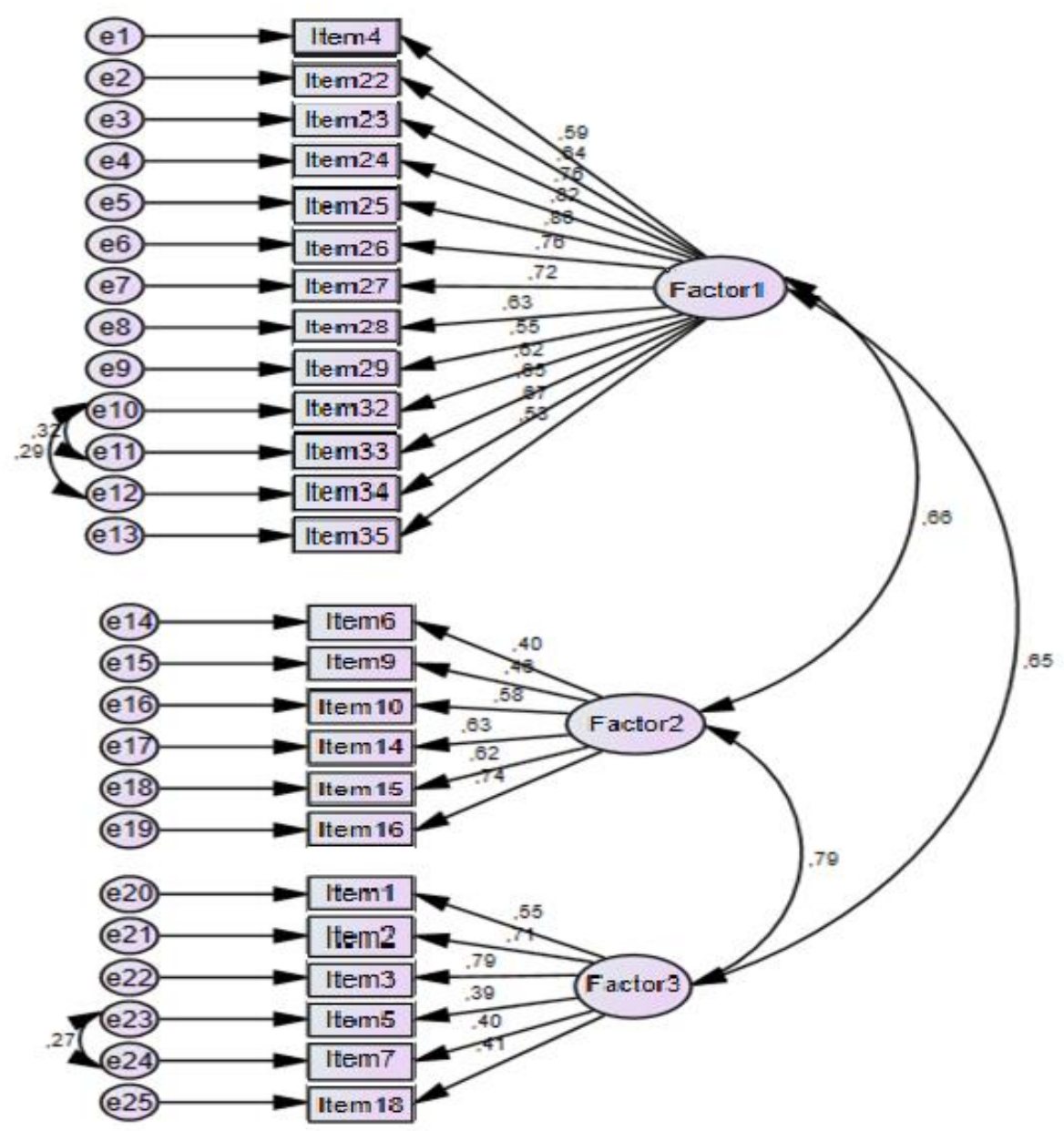

FIGURE 1. 1st level 3 factor DFA model for self-efficacy for music-assisted English teaching scale

Table 5. Fit index values of confirmatory factor analysis for self-efficacy scale

\begin{tabular}{lllll}
\hline Fit Index & $\begin{array}{l}\text { Structural } \\
\text { Equation } \\
\text { Model }\end{array}$ & Perfect Fit Criteria & Acceptable Fit Criteria & Assessment \\
\hline$\chi 2 /(\mathrm{df})$ & $536,27 /(269)=$ & $0 \leq \chi^{2} \leq 3$ & $3<\chi^{2} \leq 5$ & Perfect Fit \\
RMSEA & 1,99 & $0 \leq \mathrm{RMSEA} \leq 0,05$ & $0,05<\mathrm{RMSEA} \leq 0,08$ & Acceptable Fit \\
TLI/NNFI & 0.073 & $0,97 \leq \mathrm{TLI} \leq 1,00$ & $0,95 \leq \mathrm{TLI}<0,97$ & Acceptable Fit \\
$\mathrm{CFI}$ & 0.95 & $0,97 \leq \mathrm{CFI} \leq 1,00$ & $0,95 \leq \mathrm{CFI}<0,97$ & Acceptable Fit \\
$\mathrm{NFI}$ & 0.96 & $0,95 \leq \mathrm{NFI} \leq 1,00$ & $0,90 \leq \mathrm{NFI}<0,95$ & Acceptable Fit \\
$\mathrm{AGFI}$ & 0,91 & $0,90 \leq \mathrm{AGFI} \leq 1,00$ & $0,85 \leq \mathrm{AGFI}<0,90$ & Acceptable Fit \\
GFI & 0,92 & $0,95 \leq \mathrm{GFI} \leq 1,00$ & $0,90 \leq \mathrm{GFI}<0,95$ & Acceptable Fit \\
\hline
\end{tabular}


As presented in Table 5, according to the fit index values in the 1st Level 3-Factor DFA Model defined for 3-factor 25-item scale with exploratory factor analysis, $\chi 2 /$ (df) value was calculated as 1.99, which shows perfect fit based on the comparison with table values (Byrne, 2013). According to RMSEA fit index, 0.073 presents an acceptable fit index. TLI/NNFI, CFI, NFI, AGFI and GFI values also show acceptable fit (Schermelleh-Engel, Moosbrugger \& Müller, 2003). Consequently, pre-defined 3 -factor 25-item structure is confirmed.

Table 6. Measurement model results

\begin{tabular}{|c|c|c|c|c|c|c|}
\hline & & & $\begin{array}{l}\text { Standardized } \\
\text { Factor Loads }\end{array}$ & $R^{2}$ & T Statistic & $p$ \\
\hline Item35 & $<---$ & Factor1 & 0,53 & 0,29 & 6,211 & ,000 \\
\hline Item34 & $<--$ & Factor1 & 0,67 & 0,45 & 7,352 & ,000 \\
\hline Item33 & $<--$ & Factor1 & 0,65 & 0,42 & 7,201 & ,000 \\
\hline Item32 & $<--$ & Factor1 & 0,62 & 0,38 & 6,927 & ,000 \\
\hline Item29 & $<--$ & Factor1 & 0,55 & 0,31 & 6,388 & ,000 \\
\hline Item28 & $<--$ & Factor1 & 0,63 & 0,39 & 7,017 & ,000 \\
\hline Item27 & $<---$ & Factor1 & 0,72 & 0,52 & 7,765 & ,000 \\
\hline Item26 & $<--$ & Factor1 & 0,76 & 0,58 & 8,041 & ,000 \\
\hline Item 25 & $<--$ & Factor1 & 0,86 & 0,74 & 8,642 & ,000 \\
\hline Item24 & $<--$ & Factor1 & 0,82 & 0,67 & 8,389 & ,000 \\
\hline Item23 & $<--$ & Factor1 & 0,76 & 0,57 & 7,989 & 000 \\
\hline Item22 & $<---$ & Factor1 & 0,64 & 0,41 & 7,098 & ,000 \\
\hline Item4 & $<--$ & Factor1 & 0,59 & 0,34 & Constant & \\
\hline Item16 & $<--$ & Factor2 & 0,74 & 0,55 & 4,966 & ,000 \\
\hline Item15 & $<--$ & Factor2 & 0,62 & 0,39 & 4,699 & 000 \\
\hline Item14 & $<--$ & Factor2 & 0,63 & 0,40 & 4,722 & ,000 \\
\hline Item10 & $<--$ & Factor2 & 0,58 & 0,34 & 4,582 & 000 \\
\hline Item9 & $<--$ & Factor2 & 0,46 & 0,21 & 4,105 & ,000 \\
\hline Item6 & $<--$ & Factor2 & 0,40 & 0,16 & Constant & \\
\hline Item18 & $<--$ & Factor3 & 0,41 & 0,16 & 4,497 & ,000 \\
\hline Item7 & $<--$ & Factor3 & 0,40 & 0,16 & 4,440 & ,000 \\
\hline Item5 & $<--$ & Factor3 & 0,39 & 0,15 & 4,329 & ,000 \\
\hline Item3 & $<--$ & Factor3 & 0,79 & 0,62 & 6,950 &, 000 \\
\hline Item2 & $<---$ & Factor3 & 0,71 & 0,50 & 6,622 & ,000 \\
\hline Item1 & $<---$ & Factor3 & 0,55 & 0,30 & Constant & \\
\hline
\end{tabular}

As presented in Table 6, all values obtained from the confirmatory factor analysis confirm the construct obtained with exploratory factor analysis.

\section{Reliability}

In order to prove the applicability of the scale, internal consistency Cronbach Alpha value was taken into consideration as is done in many scale development studies. According to the analysis results, reliability coefficient for the whole scale was calculated as 0.915 . This value shows that reliability of the scale is pretty high. According to the results of the all analyses, the developed scale has three dimensions with high validity and reliability.

\section{DISCUSSION and CONCLUSIONS}


The purpose of the present research is developing a scale to be used in measuring the English teachers' self-efficacy for music-assisted English teaching. Following the scale development procedures, related literature was reviewed, and a 35-item item pool was developed with the data collected from the English teachers, who are the target audience of the scale. After receiving expert opinions on the items in the item pool, exploratory factor analysis was conducted on the draft scale for validity, which presented a 25 -item and 3-dimension scale. Then, confirmatory factor analysis was conducted on the 25-item scale on AMOS-21 package software. All values obtained from the confirmatory factor analysis confirmed the construct provided by exploratory factor analysis. For the reliability coefficient, Cronbach Alpha reliability value was calculated. As a result of all these analyses, a valid and reliable 25 -item scale was developed to measure self-efficacy for music-assisted English teaching. This developed scale can be used effectively in studies to be conducted to measure English teachers' self-efficacy perceptions for music-assisted English teaching.

The review of the related literature didn't present a measurement tool for English teachers' self-efficacy for music-assisted English teaching. However, several self-efficacy measurement tools have been developed for music education (Silver, Smith and Grene, 2001; Nielsen, 2004; Afacan, 2008; Özmenteş and Özmenteş, 2008). Many studies have been conducted reporting that music-assisted English teaching can improve students' success and attitudes in English classes (Schuster and Mouzon, 1982; Gfeller, 1983; Medina, 1990; Cengiz, 2004; Šišková, 2008; Köksal, Yağışan and Çekiç, 2013).

The higher scores obtained from the scale developed with the present research indicate higher self-efficacy, while lower score indicate lower self-efficacy. Therefore, this scale can be utilized in all studies in music and English teaching. According to the review of the related literature, there are several scales measuring the self-efficacy for music teaching and English teaching separately, yet there are no scales measuring the self-efficacy for music-assisted English teaching. The present research is important from this perspective.

With this scale, suggestions can be developed for music-assisted English teaching and developing English teachers' self-efficacy for a more effective English teaching. This is important because many studies have reported that students are more successful, their attitudes improve and learning is more permanent with music-assisted English teaching (Schuster and Mouzon, 1982; Gfeller, 1983; Medina, 1990; Cengiz, 2004; Šišková, 2008; Köksal, Yağışan and Çekiç, 2013). Therefore, English teachers' abilities and self-efficacies are very important for effective musicassisted English teaching. With this scale, teachers can measure their self-efficacy individually.

\section{REFERENCES}

Afacan, Ş. (2008). Müzik Öğretimi Öz Yeterlilik Ölçeği. Ahi Evran Üniversitesi Kırşehir Eğitim Fakültesi Dergisi (KEFAD) Cilt 9, Sayı 1, ss. 1-11.

Akkoyunlu, B.,Orhan, F. ve Umay, A. (2005). Bilgisayar Öğretmenleri İçin Bilgisayar Öğretmenliği Özyeterlik Ölçeği Geliştirme Çalışması. Hacettepe Üniversitesi Eğitim Fakültesi Dergisi (H. U. Journal of Education) 29: 1-8

Akyüz, E. H. (2018). Yapı Geçerliliği İçin Doğrulayıcı Faktör Analizi: Uygulamalı Bir Çalışma. Bitlis Eren Üniversitesi Fen Bilimleri Dergisi. BEU Journal of Science7 (2), 186-198.

Bandura, A. (1986). Social foundations of thought and action: A social cognitive theory. New Jersey: Prentice Hall.

Bandura, A. (1997). Self-efficacy: The exercise of control. New York: W. H. Freeman Company.

Byrne, B. M. (2013). Structural equation modeling with LISREL, PRELIS, and SIMPLIS: Basic concepts, applications, and programming. Psychology Press.

Campbell, D. (2003). The Mozart effect for parents: Unlocking the potential of your child. New York: Penguin publishers.

Cengiz, Y. (2004). Yabancı Dilde Sozcuk Öğretimine Muzik Kullanımının Etkilerinin Beyin Temelli Oğrenme Kuramı Isığında Arastırılması (Unpublished master's thesis). Ankara University, Ankara, Turkey

Farran, B. (2004). Predictors of Academic Procrastination in College Students. Unpublished Doctoral Dissertation. Fordham University. ABD. 
Gfeller, K. E. (1983). Musical mnemonics as an aid to retention with normal and learning disabled students. Journal of Music Therapy, 20, 179- 189.

Güvenç, H. (2010). Ders Çalışma Özyeterlik Algısı Ölçeği'nin Geliştirme Çalışması. Yüzüncü Yıl Üniversitesi, Eğitim Fakültesi Dergisi. Haziran 2010. Cilt:VII, Sayı:I, 59-69 http://efdergi.yyu.edu.tr.

Kahn, J. V. ve Best, J. (2017). Eğitimde Araştırma Yöntemleri (10. Baskı). (O. Köksal, Çev.). Konya: Eğitim Kitabevi Yayınları.

Kandemir, M. ve Özbay, Y. (2012). Academic Self- Efficacy Scale: Validity Reliability Study. Erzincan University Journal of Education Faculty Skin-Number: 14-2.

Karakaş, T. N. ve Turanlı, N. (2008). Matematik eğitimi derslerine yönelik tutum ölçeği geliştirilmesi. Gazi Üniversitesi Gazi Eğitim Fakültesi Dergisi, 28(3), 17-29

Karasar, N. (2005). Bilimsel Araştırma Yöntemi, Nobel Yayınları, s.79, Ankara.

Köksal, O., Yağışan, N. and Çekiç, A. (2013). The effects of music on achievement, attitude and retention in primary school English lessons. Procedia -Social and Behavioral Sciences 93 ( 2013 ) $1897-1900$ ISSN: $1877-0428$

Medina, S. L. (1990). The effects of music upon second language vocabulary acquisition. Paper presented at the TESOL conference. San Francisco, CA, the U.S.

Mora, C. F. (2000). Foreign language acquisition and melody singing. ELT Journal, 54(2), 146-152.

Nielsen, S. G. (2004). Strategies and self efficacy beliefs in instrumental and vocal individual practice: a study of students in higher music education. Psychology of Music, 32(4), 418-431

Özmenteș, G. ve Özmenteș, S. (2008). Müzik Yeteneğine Yönelik Özyeterlik Ölçeğinin Geliştirilmesi. 1. Ulusal Eğitimde ve Psikolojide Ölçme ve Değerlendirme Kongresi. Ankara

Özmenteș, S. (2011). Müzik Öğretimine Yönelik Özyeterlik Ölçeğinin Geliştirilmesi. Journal Of Educational And Instructional Studies in the World. November 2011, Volume 1 Issue 1 Article 5 ISNN: 21467463

Pajares, F. (1996). Self-Efficacy Beliefs in Academic Settings. Review of Educational Research, 66, 543-578.

Palmer, C. and Kelly, M. (1992). Linguistic prosody and musical meter in song. Journal of Memory and Language, 31, 525-541.

Schermelleh-Engel, K., Moosbrugger, H. and Müller, H. (2003). Evaluating the fit of structural equation models: Tests of significance and descriptive goodness-of-fit measures. Methods of psychological research online, 8(2), 23-74.

Schunk, D. H. (1985). Self-efficacy and classroom learning. Psychology in the School, 22, 208-223.

Schuster, D. and Mouzon, D. (1982). Music and vocabulary leaming. Journal of the Society for Accelerative Learning and Teaching, 7(1), 82-106.

Silver, B. B., Smith, E. V. Jr. and Grene, B. A. (2001). Astudy strategies self-efficacy instrument for use with community college students. Educational and Psychological Measurement, 61, 849-865.

Sirois, F. (2004). Procrastination and intentions to perform health behaviors: The role of self-efficacy and the consideration of future consequences. Personality and Individual Differences. 37, 115-128.

Šišková, D. (2008). Teaching vocabulary through music. Diploma Thesis. Masaryk University. Brno,Czech Republic.

Stansell, J. W. (2005). The use of music for learning languages: A review of the literature [Topic Notes]. Illinois, the U.S.: University of Illinois, Office for Mathematics, Science, and Technology Education. http://mste.illinois.edu/courses/ci407su02/students/stansell/Jon_Stansell_The_Use_of_Music_in _Learning_Languages.pdf.

Tavşancıl. E. (2002).Tutumların Ölçülmesi ve SPSS ile Veri Analizi, (1. Baskı) Ankara Nobel Yayınevi.

Ülper, H., Yayll, D. ve Karakaya, i. ( 2013). Okur Özyeterlik Ölçeğinin Geliştirilmesi. Ahi Evran Üniversitesi Kırşehir Eğitim Fakültesi Dergisi (KEFAD) Cilt 14, Sayı 1, Nisan 2013, Sayfa 85-100.

Volin, J. (1997). English through Songs. Praha, Czech Republic: LEDA.

Yağışan, N., Köksal, O. ve Harun, K. (2014). İlkokul Matematik Derslerinde Müzik Destekli Öğretimin Başarı, Tutum ve Kalıcılık Üzerindeki Etkisi. İdil,3(11), s.1-26.

Yıldırım, F. ve İlhan, Ö. İ. (2010). Genel Özyeterlilik Ölçeği Türkçe Formunun Geçerlilik ve Güvenilirlik Çalışması. Türk Psikiyatri Dergisi 2010;21(4):301-8.

Zimmerman, B. J.(1995). Self-Efficacy and Educational Development. in a. Bandura (Ed). Self Efficacy in Changing Societies. New York, Cambridge University Press.

\section{APPENDIX-1}


Self-efficacy for music-assisted English teaching draft scale

Dear teachers,

The present study is conducted in order to DEVELOP A SELF-EFFICACY FOR MUSIC ASSISTED ENGLISH TEACHING SCALE. Your answers will help me develop the Self-efficacy for Music-assisted English Teaching Scale.

For this reason, sincerity of your answers is very important for this scientific study. Thanks in advance for your contribution.

\section{Prof. Dr. Onur KÖKSAL}

DEVELOPMENT OF SELF-EFFICACY FOR MUSIC-ASSISTED ENGLISH TEACHING SCALE

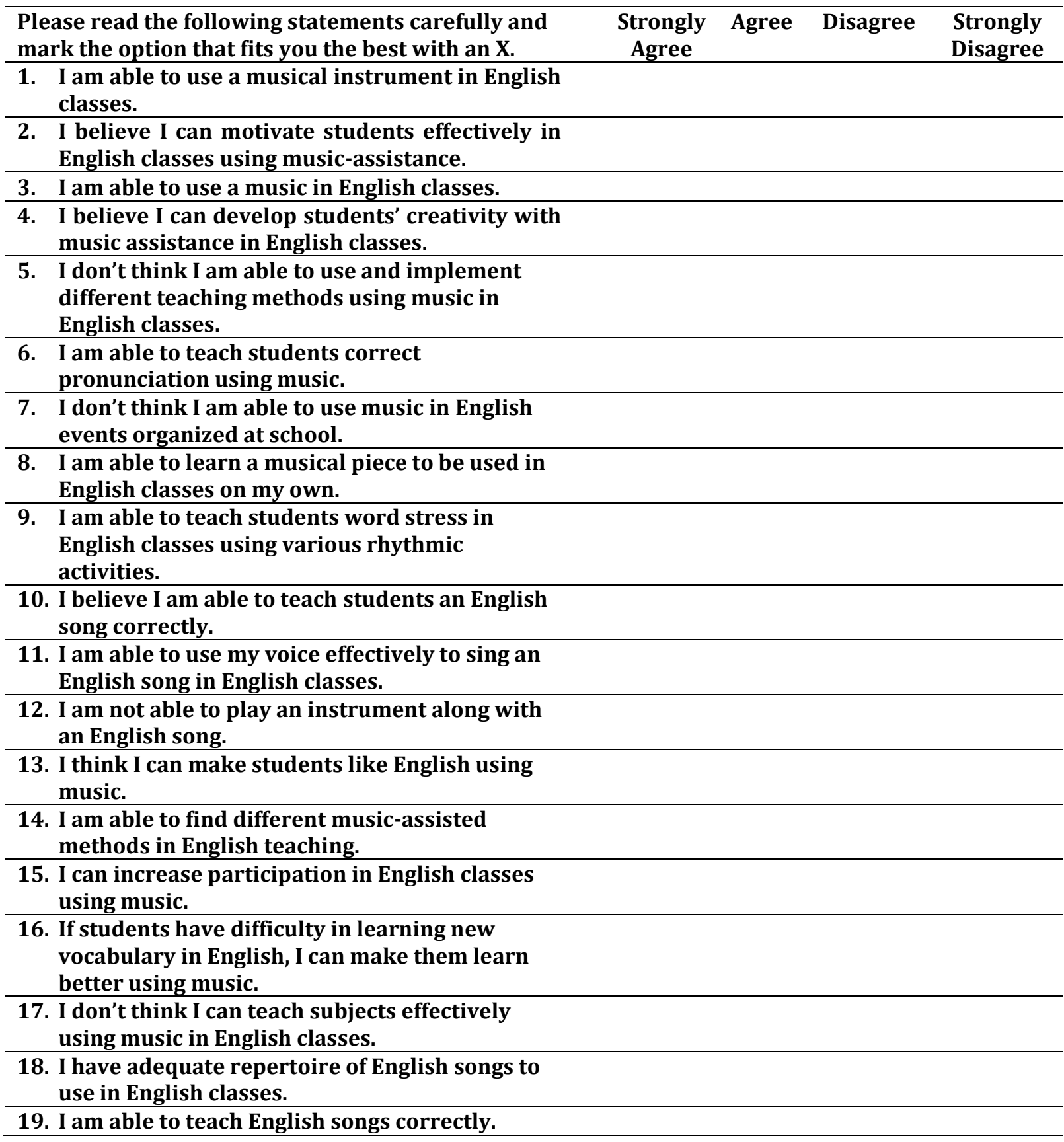


20. I don't think I am able to use music related teaching materials in English classes.

21. I can adapt a song with English lyrics.

22. I think English can be pronounced more fluently and easily using music.

23. I think English vocabulary learnt through songs are more permanent.

24. I think students enjoy classes more when English is taught with music.

25. I think students can concentrate longer in English classes done with music.

26. I think using music fitting the emotional mood of the stories taught in English classes can contribute to teaching more effectively.

27. I think I can express myself better when I use music in English classes.

28. I can teach subjects more creatively using music.

29. I think using music in English classes contributes to my professional development.

30. I don't think using music in English classes can contribute to the class.

31. I feel more sufficient in classes when I teach English with music.

32. I can teach more effectively when I use music in English classes.

33. I think using music in English classes contributes to course attainments positively.

34. I can teach subjects more easily using music in English classes.

35. I don't think using music in English classes in necessary. 


\section{APPENDIX-2}

Final version self-efficacy scale for music-assisted English teaching

\section{SELF-EFFICACY SCALE FOR MUSIC-ASSISTED ENGLISH TEACHING}

\begin{tabular}{llll}
\hline $\begin{array}{l}\text { Please read the following statements carefully and mark the } \\
\text { option that fits you the best with an X. }\end{array}$ & $\begin{array}{c}\text { Strongly } \\
\text { Agree }\end{array}$ & $\begin{array}{l}\text { Agree } \\
\text { 1. I am able to use a musical instrument in English } \\
\text { classes. }\end{array}$ & $\begin{array}{l}\text { Disagree } \\
\text { Disagree }\end{array}$ \\
\hline 2. I believe I can motivate students effectively in \\
English classes using music-assistance.
\end{tabular}

3. I am able to use a music in English classes.

4. I believe I can develop students' creativity with music assistance in English classes.

5. I don't think I am able to use and implement different teaching methods using music in English classes.

6. I am able to teach students correct pronunciation using music.

7. I don't think I am able to use music in English events organized at school.

8. I am able to teach students word stress in English classes using various rhythmic activities.

9. I believe I am able to teach students an English song correctly.

10. I am able to find different music-assisted methods in English teaching.

11. I can increase participation in English classes using music.

12. If students have difficulty in learning new vocabulary in English, I can make them learn better using music.

13. I have adequate repertoire of English songs to use in English classes.

14. I think English can be pronounced more fluently and easily using music.

15. I think English vocabulary learnt through songs are more permanent.

16. I think students enjoy classes more when English is taught with music.

17. I think students can concentrate longer in English classes done with music.

18. I think using music fitting the emotional mood of the stories taught in English classes can contribute to teaching more effectively.

19. I think I can express myself better when I use music in English classes.

20. I can teach subjects more creatively using music. 
21. I think using music in English classes contributes to my professional development.

22. I can teach more effectively when I use music in English classes.

23. I think using music in English classes contributes to course attainments positively.

24. I can teach subjects more easily using music in English classes.

25. I don't think using music in English classes in necessary. 